\title{
LA-5362-MS
}

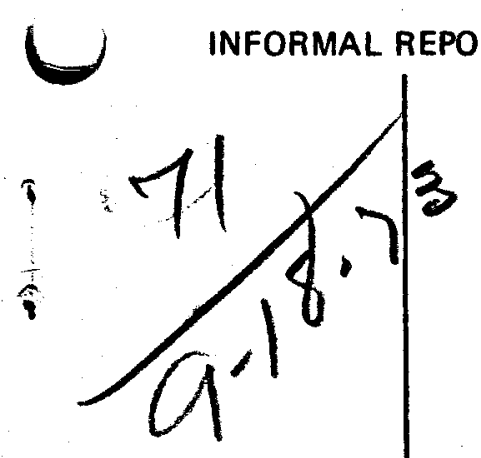

\section{Regional Geology and \\ Geophysics of the Jemez Mountains}

: scientific laboratory

- of the University of California

7 LOS ALAMOS, NEW MEXICO 87544

$\downarrow$ 


\section{DISCLAIMER}

This report was prepared as an account of work sponsored by an agency of the United States Government. Neither the United States Government nor any agency Thereof, nor any of their employees, makes any warranty, express or implied, or assumes any legal liability or responsibility for the accuracy, completeness, or usefulness of any information, apparatus, product, or process disclosed, or represents that its use would not infringe privately owned rights. Reference herein to any specific commercial product, process, or service by trade name, trademark, manufacturer, or otherwise does not necessarily constitute or imply its endorsement, recommendation, or favoring by the United States Government or any agency thereof. The views and opinions of authors expressed herein do not necessarily state or reflect those of the United States Government or any agency thereof. 


\section{DISCLAIMER}

Portions of this document may be illegible in electronic image products. Images are produced from the best available original document. 
This report was prepared as an account of work sponsored by the United States Government. Neither the United States nor the United States Atomic Energy Commission, nor any of their employees, nor any of their contractors, subcontractors, or their employees, makes any warranty, express or implied, or assumes any legal liability or responsibility for the accuracy, completeness or usefulness of any information, apparatus, product or process disclosed, or represents that its use would not infringe privately owned rights.

In the interest of prompt distribution, this LAMS report was not edited by the Technical Information staff.

Printed in the United States of America. Available from National Technical Information Service

U. S. Department of Commerce 5285 Port Royal Road Springfield, Virginia 22151

Price: Printed Copy \$4.00; Microfiche $\$ 0.95$ 


\section{Regional Geology and \\ Geophysics of the Jemez Mountains}

by

Francis G. West

NOTICE

This report was prepared as an eccount of work

ponsored by the United States Government. Neither

Co United States nor the United States Atomic Eneror

Commission; nor eny of their employees, nor any of

Their contractors, subcontractors, or their employoes,

makes any warranty, express or implied, or assumes

legal liability or responsibility for the

pleteness or usefulness of any information

product or process disclosed or represents, sparatus,

product or process disclosed, or represents that its use
would not infringe privately owned rights. 
REGIONAL GEOLOGY AND GEOPHYSICS OF THE JEMEZ MOUNTAINS

by

Francis G. West

ABSTRACT

The western margin of the Rocky Mountain tectonic belt is the initial site for the Los Alamos Geothermal Project. Igneous activity in the area culminated with the formation of a collapsed volcanic caldera and the deposition of thick. beds of tuff. Geophysical studies indicate that the region is one of relatively high-terrestrial heat flow, low-crustal density, low-crustal seismic velocities, low-crustal magnetoelectric impedance, and thin crust.

\section{INTRODUCTION}

The Los Alamos Scientific Laboratory has initiated a program for the research and development of geothermal energy. Potential for development of geothermal energy varies areally and with depth below the earth's surface. This spatial distribution of geothermal energy is the culmination of all geological processes that were ever active. Assessment of the geothermal potential of an area requires at a minimum all available geological and geophysical information. The following is a brief review of that information for the proposed project area with an attempt by the author to assemble it into the most reasonable picture.

\section{GEOLOGY}

The area proposed for initial experiments in the development of a man-made geothermal-energy system, the Jemez Mountains, lies in the southern part of the Rocky Mountain belt in what is known as the Rio Grande trough or rift. The trough is bounded geologically on the east by the Texas foreland, on the west by the colorado plateau, and on the southwest by the Basin and Range province. This cordilleran system, the Rocky
Mountain belt, extends northward into canada and southward into Mexico. The Rio Grande trough extends from central colorado through southern New Mexico. 1

The Rockies have a long history of structural activity, which was culminated during the Laramide orogeny with a dramatic uplift of the belt by compressional forces of global magnitude. The uplifted belt has a width of 50 to 100 miles in New Mexico. The east limb of the New Mexico part of the uplift characteristically exhibits more folding and is wider than the west limb, which is flatter and terminates more abruptly. The east limb has been folded to the extent. that it was described as a synclinorium. 2 The uplift was eroded to an undulating plain, the remnants of which cap many of the peaks of the present Rockies. subsequently, parts of the belt went into tension causing linearcollapse features such as the Rio Grande Valley, a complex structural trough. The trough was formed by en echelon blocks faulted down in a stair-step fashion, as is indicated in Fig. 1, with an occasional relatively upthrown block in the sequence. It was during this period in geologic time that extensive volcanic extrusion and intrusion began to 


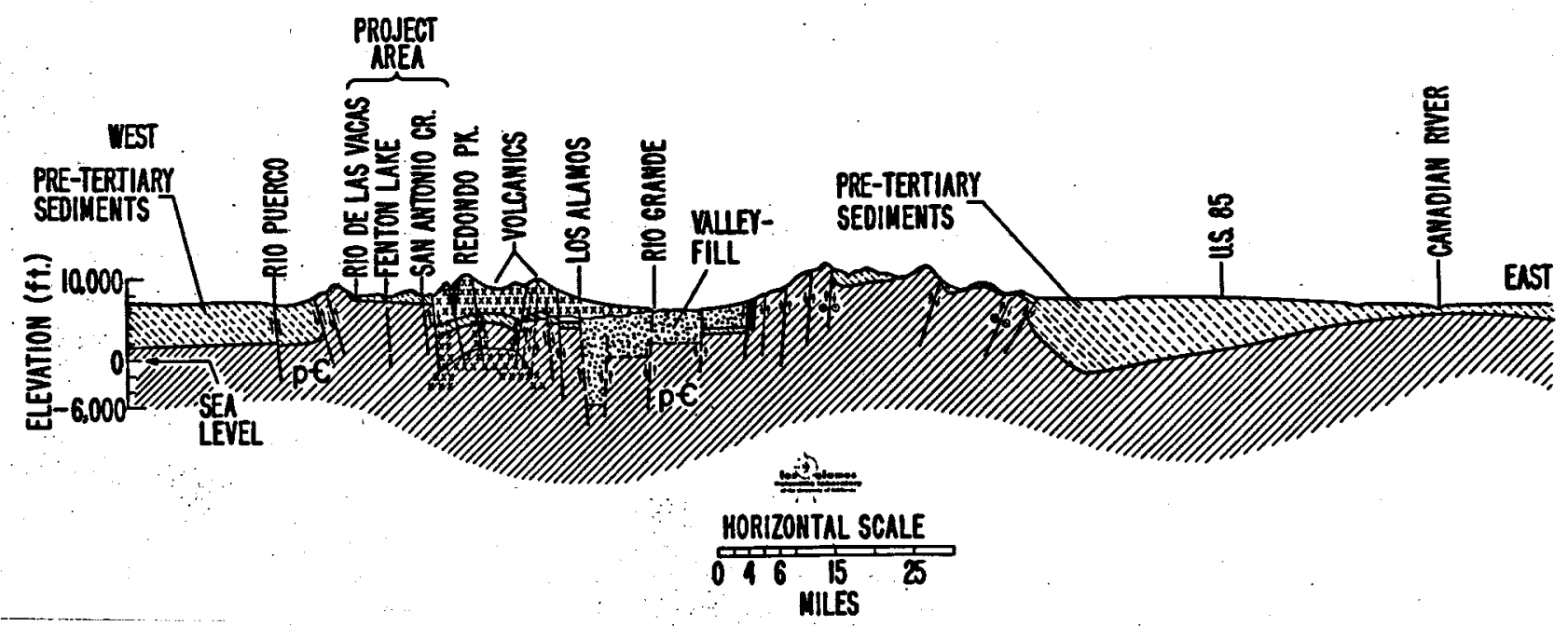

Fig. 1. Regional geological cross section.

occur along the belt, and especially along the Rio Grande trough. ${ }^{3}$ Initially, the volcanism occurred mainly along the west side of the trough; however, during the later stages, the activity was along the medial axis. The early rocks, which are finer grained, show evidence of more crustal contamination as compared to the later rocks. 4 The complete significance of this petrographic and geographic distribution of vulcanism is not presently known, but has been noted in other rift structures around the world. Although the surface geologic and geophysical characteristics of most of the major rifts are generally known, very few, if any, of the characteristics are known at depth.

An apparent westward offset of the southern part of the Rio Grande trough marks the southern boundary of the Jemez-Nacimiento uplift in which the proposed project area is located. The Nacimiento high-angle reverse fault which brings granitic rocks to the surface sharply defines the west side of the uplift and the east side of the San Juan Basin. 5 Gravity faulting down into the Chama Basin-Abiquiu embayment area forms the north side of the uplift. The stepfaulting characteristic of the Rio Grande trough makes the definition of the east side a little arbitrary. From a local perspective, the Jemez-Nacimiento uplift is a structural island with a diameter of approximately 30 miles. The proposed project area is situated roughly in the center of the uplift.

The Rocky Mountain belt has been structurally active in one form or another for most of geologic time, and it is quite likely that most of the rock formations will have a unique original character and thickness in the project area. Repeated cycles of uplift and erosion have probably further modified the original formational thicknesses of the metamorphic as well as the sedimentary rocks. In the western part of the uplift the process has completely stripped the sedimentary and metamorphic rocks leaving the granitic rocks exposed.

Volcanic activity began in the area with lava of various rock types erupting from numerous fault-oriented centers. 6 It is only reasonable that the forces responsible for creating the offset in the trough also provided the zones of weakness for the locus of volcanism. Volcanic rocks ultimately covered over 1,000 square miles of area. 7 The growing lava fields began coalescing and forming low shields. The thickening shield reduced the number of eruptive centers, which in turn caused the eruptions to be more violent, especially during the eruption of lava having a high-gas content. 
Near the center of this volcanic pile a catastrophic eruption finally broke out, which laid down an ash-flow tuff that attained a local thickness of $1,000 \mathrm{ft}$--representing a total volume of rock estimated to be on the order of 50 cubic miles. (Ash-flow tuffs are laid down by immense clouds of extremely hot, dense gases and pyroclastics, like the one that buried the city of Pompeii.) The roof of the partially-emptied magma chamber. having lost its support, collapsed to form a structure known as a caldera. The valles caldera, one of the world's largest, has a diameter of 12 to 15 miles. The roof collapse created a circular fault zone, 2 to 3 miles in width, around the caldera's edge. Lavas flowed up this ring of fractures into the caldera floor. During a period of quiescence, lake beds were deposited in the caldera. A final surge of volcanic activity caused the caldera floor to be upwarped into a dome, while lavas were being extruded from the ring fracture zone to form a ring of lava domes. The caldera floor has since been partly covered by another layer of lake beds. leaving the lava domes protruding like icebergs. Contemporaneous with the volcanic deposition at all times was of course considerable erosion and sedimentary deposition, especially toward the Rio Grande trough to the east. The tectonic forces which created the faults and influenced the location of the volcanism continued through all of the volcanic periods and probably well past the last surge of volcanic activity. Post-volcanic faulting has occurred to the east of the caldera and along a line southwest from the center of the caldera. 8

The project area is just to the west. of the valles caldera. The center of the caldera is a distance of about 8 miles and the ring-fracture zone is about 3 miles from the project area. The project area is covered by the thick ash-flow tuff previously mentioned. Other minor, assorted volcanic units are encountered before reaching the sedimentary and metamorphic sequence of rocks that overlies the granite. The project area spans the first major fault block outside of the caldera proper. Since the volcanic magma probably followed faults in its upward movement, the magma chamber is probably steep sided. Various environments of interest relative to geothermal-energy investigations are therefore available within a small area.

\section{GEOPHYSICS}

As one might expect in an orogenic zone such as the Rocky Mountain-Rio Grande belt, the geophysics are anomalous. Rocks of appreciably different physical properties have been placed in juxtaposition by the tectonic and igneous activity. Erosional processes have created various anomalous sequences of formations. Extrusive and intrusive igneous processes are responsible for a number of the geophysical anomalies. Heat Flow

Tectonic provinces have long been known as areas of higher than average terrestrial heat flow, 9 and the Rocky Mountain belt is no exception. The mean heat flow of a tectonic province appears to be a function of the age of the activity. The relatively old Texas foreland, east of the Rio Grande rift zone, has a nominal heat-flow value of 1.1 $\mu \mathrm{cal} / \mathrm{cm}^{2}$ sec. The Rocky Mountain and the Basin and Range provinces, which are moderately young, have heat flow values that range from 1.5 to $3.4 \mathrm{\mu cal} / \mathrm{cm}^{2} \mathrm{sec} 10$ The above-average heat flow may reflect elevated Isotherms in the crust, increased thermal conductivity of the crustal rocks, or both. certainly the heat flow is enhanced by the abundance of silicic rocks which contain above-average amounts of heatproducing radioactive elements.

\section{Gravity}

The Bouguer Gravity Map of the region exhibits a general northeast-southwest trend of anomaly closures along the Rocky Mountain belt. ${ }^{11}$ The axis of the gravity lows is along the western edge of the Rio Grande Valley, with a parallel trend of gravity highs farther to the west. 12 To the east of the 
Rio Grande trough, the anomalies are of a more random nature or at least they do not have the marked trend found along the trough itself: The Jemez caldera coincides with one of the gravity lows. The negative Bouguer anomalies can be explained in terms of a crust that is thicker than normal or that is less dense than normal. A map of relatively low-density silicic rocks in the western United States shows a striking resemblance to the Bouguer Gravity Map. ${ }^{13}$ The Jemez caldera is known to be formed from low-density silicic rocks, which agrees with its expression as a gravity low.

The Nacimiento ridge of gravity contours drops uniformly eastward across the project area to the caldera gravity low. since the gravity map in the project area is somewhat featureless, except for the decrease in gravity eastward which corresponds to the attitude of the basement rocks, it appears that no major structures exist in the basement rocks. To the south of the project area, the Jemez Springs fault is expressed by a small northeast trending ridge in the contours. The west-trending gravity trough to the north of the project area indicates that possibly the structural trough on the northeast side of Nacimiento Peak continues eastward into the subsurface. Seismic

A fringe benefit of nuclear-device testing at the Nevada Test site has been the opportunity to study the regional variation of crustal-seismic-transmission characteristics. 14 The compressional wave velocity seems to $v$ ary in a systematic fashion with the geologic environment. 15 The velocity also apparently varies with crustal thickness; where the crust is thick the velocity tends to be high, and where the crust is thin the velocity is low. ${ }^{16}$ The crustal thickness interpreted from the seismic records indicates that a crustal thinning $\propto$ curs west of the Texas foreland, with the BasinRange province having the thinnest crust. 17 In general, the area of crustal thinning is also an area of unusually high attenuation of seismic.wave energy. 18 Maps of seismicwave travel-time anomalies correlate reasonably well with areas of known high heat flow. This has led to an explanation of the relationship of crustal parameters based on a partial crustal melting. 19 Recent laboratory results indicate that the relationship can be explained on the basis of the variation of elastic constants with temperature and pressure. 20

Magnetics

Various types of magnetic surveys have been performed in the region. It has been found that low-bandpass-filtered aeromagnetic profiles of the static field generally. become much flatter as one proceeds westward from the plains across the Rocky Mountain belt. 21 The aeromagnetic maps of the West reflect the relative youth of the area and the relative lack of mafic rocks. Aeromagnetic maps of the western United states have been interpreted as indicating a continuance eastward of the Pacific transcurrent-fracture zones associated with seafloor spreading. 22 . This type of global structural feature would assist in the explanation of the apparent westward offset of the Rio Grande rift on the south side of the Jemez uplift. The aeromagnetic map of the project area reflects the varied geologic history of the area. 23 The Nacimiento Mountains and the Jemez Plateau have north-south trending anomalies with subsidiary east-west trending anomalies. The trend of these anomalies is probably controlled by metamorphic-basementrock features such as the fracture pattern. The Jemez Caldera is outlined by anomalies with an arcuate pattern, especially in the area of the ring dikes. The project area is in a saddle between the metamorphicgenerated anomalies and those associated with the caldera.

Magnetoelectric and geomagnetic profiles of the western United states have suggested that the region has a unique reaction to magnetic events with periods of 
about 1 to 20 minutes. ${ }^{24-26}$ The interpretation of the crustal profiles is that to varying degrees the region is one of relatively low electrical impedance. 27 The relationship of the resistivity of rocks with temperature suggests that the anomalies are due in part to thermal enhancement. ${ }^{28-29}$ The preliminary maps of heat flow correlate well with magnetic reaction maps. Crustal thicknesses inferred from transient magnetic studies agree well with seismic studies. ${ }^{30-31}$ It appears that heat-flow anomalies of regional nature can be delineated by magnetoelectrics, while detailed mapping of these anomalies can be accomplished by geomagnetic soundings. 32 The skin effect, which is frequency dependent, controls the depth of these investigations. Geomagnetics, as an exploratory tool, are in the developmental stage, both from the standpoint of field methods and interpretation. ${ }^{33}$ It appears quite likely that this method will see greatly increased use in the solution of not only

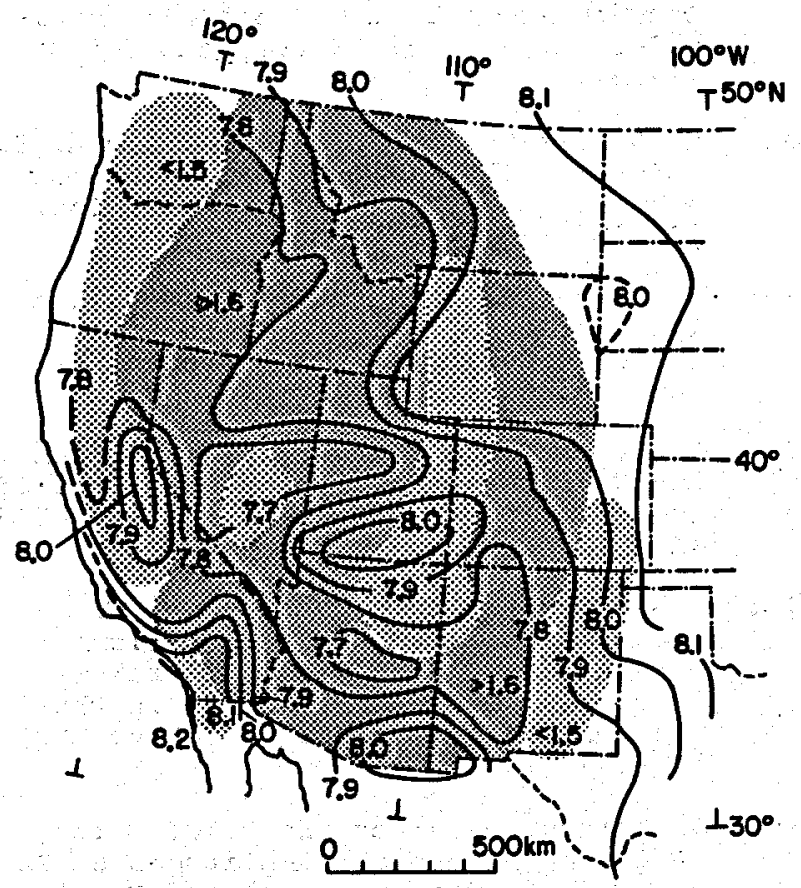

Fig. 2. Contours of Pn velocity (modified from Archambeau 1969). stippled area--heat flow units (modified from sass et al 1971). terrestrial heat-flow problems but basic problems of the structural features and processes of the earth's interior.

\section{SUMMARY}

Comparison of the various geophysical maps shows that in general the regional anomalies are coincident (see Figs. 2 and 3 ). Terrestrial heat flow appears to be mainly a function of the thickness, thermal conductivity. and tectonic age of the crust. The seismologists have explained their anomalies as resulting from a partial crustal melting or the emplacement of a special rock type. It appears that elevated isotherms in the crust cause a reduction in the shear modulus and density with a resulting zonal reduction in seismic velocity and increased attenuation of seismic energy. Gravity-low anomalies can be explained by an abundance with depth of high-silicate low-density rocks. Thermal enhancement of the crust and zonal hydration of rocks at depth offer

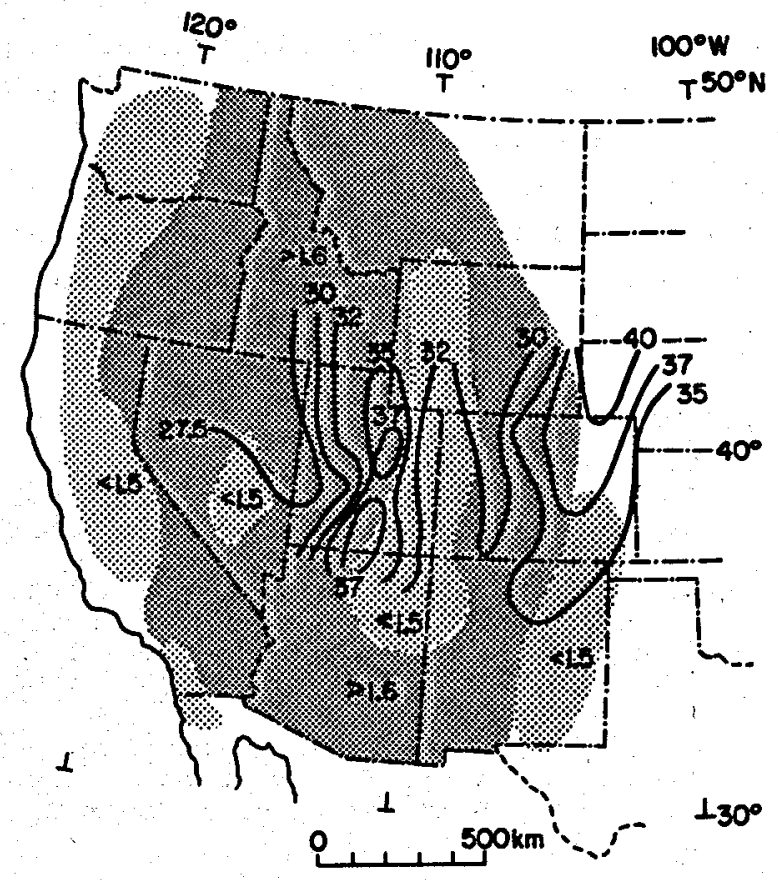

Fig. 3. Contours of vertical magnetic component ranges in gama for a daily variation (modified from Reitzel et al. 1970). Stippled area-heat flow units (modified from sass et al. 1971). 
a source for the magnetic and electric anomalies. 34

Unfortunately, a completely interdisciplinary approach to the problem of the relationship of the various anomalies has not been made. Several investigators have made commendable, but incomplete, attacks on the problem. A synthesis of the geologic, geophysical, and chemical facts suggest a thermally-young region of predominately low-density silicic rocks which are hydrated at depth to give a petrographic zone with an unusual sensitivity of the elastic and electrical properties to temperature and pressure.

In summary, the Rocky Mountain-Rio Grande trough is unique in the geology of the United states, and, to a large extent, so is its geophysics. The belt marks a continental-magnitude change in structure, crustal thickness, geophysical characteristics, and terrestrial heat flow. The project area is situated near the transition of the regional geologic structure, the geophysical anomalies, the heat-flow anomalies, and the volcanic zone. A complete understanding of the processes that cause all of these anomalies to be coincident would be of great scientific importance. Certainly any meaningful exploration and exploitation of geothermal energy will require such a basic understanding.

\section{REFERENCES}

1. C. E. Chapin, "The Rio Grande Rift, Part I: Modifications and Additions," N. M. Geol: Soc. 22, 191-201 (1971).

2. E. H. Baltz, "Stratigraphy and History of Raton Basin and Notes on San Luis Basin, Colorado-New Mexico," Bull. An. Assoc. Petr. Geol. 49, 2041-2075 (1965).

3. J. Gilluly, "Volcanism, Tectonism, and plutonism in the Western United States," Geol. Soc. Anerican Special Paper 80, 1-67 (1965).

4. P. W. Lipman, "Alkalic and Tholeiitic Basaltic Volcanism Related to the Rio Grande Depression, Southern Colorado and Northern New Mexico," Geol. Soc. Am. Bul1. 80; 1343-1354 (1969).
5. I. S. Woodward, W. H. Kaufman, J. B. Anderson, "Nacimiento Fault and Related Structures, Northern New Mexico," Geol. Soc. Pra. Bull. 83, 2383-2396 (1972).

6. R. L. Smith, and R. A. Bailey, "The Bandelier Tuff: A Study of Ash-Flow Eruption Cycles from Zoned Magma Chambers," Bull. Volcanologique 29, 83104 (1966).

7. C. S. Ross, R. I. Smith, R. A. Bailey, "Outline of the Geology of the Jemez Mountains, New Mexico," N. M. Geol. Soc. 12, 139-143 (1961).

8. D. B. Slemmons, "Analysis of Fault Activity Near the Proposed Geothermal Test Site, Los Alamos Scientific Laboratory, Jemez Mountains, New Mexico," to be published as a Los Scientific scientific Laboratory report.

9. J. G. Sclater, "New Perspectives in Terrestrial Heat Flow," Tectonophysics 13. 257-291 (1972).

10. R. R. Roy, D. D. Blackwell, and E. R. Decker, "Continental Heat Flow," in The Nature of the Solid Earth, E. C. Robertson (McGraw-Hili, Inc.. New York, 1972). Chap. 19,.pp. 506-543.

11. U. S. Air Force, Transcontinental Geophysical Survey $\left(35^{\circ}-39^{\circ} \mathrm{N}\right)$, Bouguer Gravity Map from $100^{\circ}$ to $112^{\circ} \mathrm{W}$ Longitude," U. S. Geol. Surviey Map I-533B (1968).

12. H. R. Joestring, J. E. Case, and L. E. Cordell, "The Rio Grande Trough Near Albuquerque, New Mexico," Geol. Soc. 12. $148-150$ (1961).

13. J. G. Moore, "K/Na Ratio of Cenozoic Igneous Rocks of the Western United states," Geochimica et Cosmochimica Acta 26, 101-130 (1962).

14. I. C. Pakiser, "Structure of the Crust and Upper Mantle in the Western United states," J. Geophys. Res. 68, 5747-5756 (1963).

15. D. J. Stuart, J. C. Roller, W. H. Jackson, and G. B. Mangan, "Seismic Propagation Paths, Regional Traveltimes, and Crustal structure in the Western United States," Geophys. 29. 178-187 (1964).

16. J. Jordan, R. Black and C. C. Bates, "Patterns of Maximum Amplitudes of $\mathrm{Pn}$ and $P$ Waves Over Regional and Continental Areas," Bull. Seismol. Soc. An. 55, 693-720 (1965).

17. C. B. Archambeau, "Fine structure of the Upper Mantle," J. Geophys. Res. 74, 5825-5865 (1969). 
18. A. L. Hales and H. A. Doyle, "P and $S$ Travel Time Anomalies and Their Interpretation," Geophys. J. R. Astr. Soc. 13. 403-415 (1967).

19. S. C. Soloman, "Seismic-Wave Attenuation and Partial Melting in the Upper Mantle of North Anerica," J. Geophys. Res. 77. 1483-1502 (1972).

20. O. I. Anderson, "The Role of Experimental Physical Acoustics in Geophysics," Tectonophysics 13, 521-540 (1972).

21. I. Zietz et al.. "Aeromagnetic Investigation of Crustal structure for a Strip Across the Western United States," Geol. Soc. Am. Bull. 80, 1703-1714 (1969).

22. M. D. Fuller, "Expression of E-W Fractures in Magnetic Surveys in Parts of the U.S.A.," Geophys. 29, 602-622 (1964).

23. I. Zietz and J.R. Kirby, "Transcontinental Geophysical Survey $\left(35^{\circ}-39^{\circ} \mathrm{N}\right)$, Magnetic Map from $100^{\circ}$ to $112^{\circ} \mathrm{W}$ Longitude." U. S. Geol. Survey Map I-533A (1968).

24. B. Canner, W. H. Cannon, and C. E. Livingstone, "Geomagnetic Depth Sounding and Upper Mantle structure in the Cordillera Region of Western North America," J. Geophys. Res. 72, 63356351 (1967).

25. U. Schmucker and J. Jankowski, "Geomagnetic Induction studies and the Electrical state of the Upper Mantle," Tectonophysics 13, 233-256 (1972).
26. H. Porath and D. I. Gough, "Mantle Conductive Structures in the Western United States from Magnetometer Array Studies," Geophys. J. R. Astr. Soc. 22. 261-275 (1971).

27. T. Rikitake, "Electric Conductivity Anomaly in the Earth's Crust and Mantle," Earth-Sci. Rev. I. 35-65 (1971).

28. S. Uyeda and T. Rikitake, "Electrical Conductivity Anomaly and Terrestrial Heat Flow," J. Geomag. Geoelec. 22 . 75-90 (1970).

29. R. E. Warren et al.. "A Comparison of Terrestrial Heat Flow and Transient Ceomagnetic Fluctuations in the Southwestern United States," Geophys. 34. 463-478 (1969).

30. J. Mitchell and M. Landisman, "Electrical and Seismic Properties of the Earth's Crust in the southwestern Plains of the U.S.A.." Geophys. 36. 363-381 (1971).

31. J. S. Reitzel et al.. "Geomagnetic Deep Sounding and Upper Mantle structure in the Western United states." Geophys. J. R. Astr. Soc. 19, 213-235 (1970).

32. B. Caner and W. H. Cannon, "Geomagnetic Depth-Sounding and Correlation with Other Geophysical Data in Western North Anerica," Nature 205, 927-929 (1965).

33. G. V. Keller, "Induction Methods in Prospecting for Hot Water," Geothermics 2. $318-332(1970)$.

34. R. D. Hyndman and D. W. Hyndman, "Water Saturation and High Electrical Conductivity in the Lower Continental Crust," Earth Planet. Sc. Letters $4,427-432$ (1968). 